\title{
Developing Social Studies Teaching Materials Based on Multimedia EPUB for The Effectiveness on Learning Outcomes
}

\author{
$1^{\text {st }}$ M. Irfan Islamy ${ }^{1}, 2^{\text {nd }}$ Muhammad Kholis Amrullah ${ }^{1}, 3^{\text {rd }}$ Agus Riwanda $^{1}, 4^{\text {th }}$ Nuril \\ Mufidah $^{1}, 5^{\text {th }}$ Luthfiya Fathi Pusposari ${ }^{1}, 5^{\text {th }}$ Abdul Fattah ${ }^{1}$ \\ \{irfan.islamy87@uin-malang.ac.id ${ }^{1}$, kholisamrullah90@yahoo.co.id ${ }^{1}$, agusriwanda90@gmail.com¹, \\ nurilmufidah86@uin-malang.ac.id ${ }^{1}$, luthfiya@pips.uin-malang.ac.id ${ }^{1}$, abdul.fattah@uin-malang.ac.id $\left.{ }^{1}\right\}$ \\ UIN Maulana Malik Ibrahim Malang, Indonesia ${ }^{1}$
}

\begin{abstract}
The aims of this study 1) to develop of Social Studies teaching materials based on multimedia EPUB 2) To determine the effectiveness on learning outcomes of the development of social studies teaching materials based on multimedia EPUB. This study uses a development method based on the Dick and Carrey model. 1) The results of the development are informed from the validation of material experts who get $85 \%$ in the effective category. The results of the validation of linguists, media and design experts receive $89 \%$ percent in the effective category. Based on the percentage obtained, the Social Studies teaching materials based on multimedia EPUB meet the worthy standards of test. 2) The results of the trial on the learning of the Social Studies teaching materials based on multimedia EPUB obtain a score of $72 \%$ which states that the increase of posttest is influenced by the success of the use of teaching materials based on multimedia EPUB, so that the development of Social Studies teaching materials based on multimedia EPUB can be effectively used for the learning of Social Studies.
\end{abstract}

Keywords: social studies; teaching materials; development multimedia epub

\section{Introduction}

Electronic books (e-book) are digital version books that are compatible with various electronic devices by offering practicality and interaction in digital formats that are interesting rather than printed books [1] [2]. The term e-book becomes popular than digital objects that are designed to be accessible online and can be read via a PC, netbook or smartphone [3] [4]. The use of e-books today looks very massive and more popular and can be continued to develop as a the first choice, not just as an alternative than printed books [2] [5]. This is due to the rapid technological development, so that users can easily share literacy only through applications on an electronic device, like a smartphones [6].

With the increasing number of e-book readers and the availability of reading experience with various electronic devices such as smartphones, tablets, netbooks and other devices of affordable prices, reinforced by the use of e-ink technology adoption that helps reduce eye strain and helps users read below sunlight, large battery capacity (3000-4000mah), and enhanced e-reader options for highlighting, bookmarking, and adding notes make the e-book the top choice for consumers.[5] 
There are various e-book formats. One of which is a familiar format, namely Portable Document Format (PDF) which can display various document formats [7]. However, PDF has weaknesses, including difficulties when editing text, displaying video, and the ability to adjust on a small device screen, like a smartphone [2] [8]. Electronic Publication (EPUB) is an ebook format that offers the ability to overcome deficiencies in the PDF format, including the ability to adjust the appearance of electronic devices, displaying image formats such as JPEG, PNG, and SVG [2], [8]. EPUB was developed by the International Digital Publishing Forum (IDPF), with an extension (.EPUB), with the latest version of EPUB 3 (latest version 3.1) based on HTML5, SVG, CCS3, and Javascript [9] [10] [11].

The advantages of EPUB 3 allow web components to be summarized in a book that can host and stream multimedia content (images, audio and video), and contain features that support the world of education, such as quiz and interesting interaction components [9]. With all these advantages, EPUB facilitates lecturers and teachers to facilitate active and interactive learning for students by presenting digital-based teaching materials [12], in order to assist them to learn independently and overcome learning difficulties [13]. Enriched with multimedia content, EPUB brings students to virtual classrooms that provide a variety of rich learning experiences in media and interactive content, exciting and intensifying their learning processes to improve learning outcomes [14]. The presence of EPUB 3 format will open the gate of pedagogical opportunities that are very various and challenging than printed books, especially at the tertiary level which is supported by the development of e-learning, blended and hybrid learning, as well as easier opportunities to own and get technology and information-based learning tools, including teaching materials [3] [9].

The courses of Social Studies that are presented at level 1 of 3 levels in the Department of Teacher Education for Islamic Elementary School. The basis of this research begins with the analysis of teaching material needs, in which $88 \%$ of students stated that they needed teaching materials of social studies, $74 \%$ of them chose to use electronic devices in learning. The new EPUB 3 format is the ideal format for accelerating the development of teaching materials for basic social science subjects for elementary schools that are loaded with picture and video content to achieve learning objectives. Research shows the effectiveness of digital-based teaching materials, especially multimedia EPUB format in the world of education can affect students' interest and learning outcomes [6] [15] [16] [17] [18] [19] [20]. The use of EPUB is also available to assist blind people in the learning process [21]. The presence of learning resources with EPUB extension due to several factors, which can be accessed easily whenever and wherever using a smartphone, especially Android-based, ease of use, the concept of material supported by the video and the looks, can adjust the device screen and can load many images with an attractive layout.

\section{Methods}

The type of research used is development. The development model refers to the adaptation of the Dick and Carey procedural model [22]. The number of college students who purposively became the subject of this study were 160 people who took the courses of Social Studies on the Department of Teacher Education for Islamic Elementary School. Software used to develop teaching materials convert to EPUB format is the Sigil application.

The research hypothesis uses the null hypothesis and alternative hypothesis [23]. The null hypothesis is the achievement of students before and after using the same EPUB. An 
alternative hypothesis is that the achievement of students before and after using EPUB is not the same.

The research carried out through 3 stages, 1) the stages of product design using the Dick $\&$ Carey model [22], 2) the stages of product design testing, 3) the stages of product testing using the one group pre-test-post-test design [24]. Experiments were conducted on 115 students from 160 students. Analysis of experimental results employed t-test with paired samples [23].

\section{Result and Discussions}

The results of material expert validation on the development of Social Studies teaching materials based on multimedia EPUB obtain $85 \%$ in the effective category. The results of the expert validation of linguists, media and design receive $89 \%$. Based on the percentage obtained, the instruction to development of Social Studies teaching materials based on multimedia EPUB meets the worthy standards of user trial. follows.

The results of product trials using the one group pre-test post-test design can be seen as

Table 1. Paired Samples Statistics

\begin{tabular}{|rc|r|r|r|r|}
\hline & \multicolumn{1}{|c|}{ Mean } & \multicolumn{1}{c|}{$\mathrm{N}$} & Std. Deviation & Std. Error Mean \\
\hline \multirow{2}{*}{ Pair 1 } & pre-test & 54.64 & 115 & 12.772 & 1.191 \\
& post-test & 70.3478 & 115 & 10.68615 & .99649 \\
\hline
\end{tabular}

The table above shows that the overall increase in the average score of participants 15.71 points. A score of 70 is the student's minimum achievement score in the course. Based on the comparison analysis of the average pre-test and post-test, the presentation Social Studies teaching materials based on multimedia EPUB can assist students to achieve minimum standards.

Table 2. Paired Samples Correlations

\begin{tabular}{|ll|r|r|r|}
\hline & \multicolumn{1}{|c|}{$\mathrm{N}$} & Correlation & \multicolumn{1}{c|}{ Sig. } \\
\hline Pair 1 & $\begin{array}{l}\text { pre-test \& post- } \\
\text { test }\end{array}$ & 115 & .852 & .000 \\
\hline
\end{tabular}

The table above shows the correlation coefficient between pre-test and post-test values. The correlation coefficient is 0.852 . If it continues to the analysis of determination, it is necessary to square the correlation coefficient so that the result becomes 0.72 . If the determination number is multiplied by one hundred, it will find a value of $72 \%$. This means that $72 \%$ of post-test's 15.71 points increase is influenced by the successful use of the Social Studies teaching materials based on multimedia EPUB. While $28 \%$ is influenced by other factors outside this research. 
Table 3. Paired Samples Test

\begin{tabular}{|c|c|c|c|c|c|c|c|c|c|}
\hline & \multicolumn{5}{|c|}{ Paired Differences } & \multirow[t]{3}{*}{$\mathrm{t}$} & \multirow[t]{3}{*}{$\mathrm{df}$} & \multirow{3}{*}{$\begin{array}{l}\text { Sig. (2- } \\
\text { tailed) }\end{array}$} \\
\hline & & \multirow[t]{2}{*}{$\begin{array}{c}\mathrm{M} \\
\text { ea } \\
\mathrm{n}\end{array}$} & \multirow[t]{2}{*}{$\begin{array}{l}\text { Std. } \\
\text { Devia } \\
\text { tion }\end{array}$} & \multirow[t]{2}{*}{\begin{tabular}{|l} 
Std. \\
Error \\
Mean
\end{tabular}} & \multicolumn{2}{|c|}{$\begin{array}{l}95 \% \text { Confidence } \\
\text { Interval of the } \\
\text { Difference }\end{array}$} & & & \\
\hline & & & & & Lower & Upper & & & \\
\hline $\begin{array}{l}\mathrm{Pa} \\
\text { ir } \\
1\end{array}$ & $\begin{array}{l}\text { pre- } \\
\text { test } \\
- \\
\text { pos } \\
\text { t- } \\
\text { test }\end{array}$ & $\begin{array}{r}15 \\
.7 \\
04 \\
35\end{array}$ & $\begin{array}{r}6.692 \\
46\end{array}$ & .62408. & $\begin{array}{r}16.940 \\
64\end{array}$ & $\begin{array}{r}14.4680 \\
6\end{array}$ & $\begin{array}{r}25 . \\
164\end{array}$ & 114 & .000 \\
\hline
\end{tabular}

The $t$-test value obtained is $-25,164$. This number becomes 25,164 [25] with $t$ count (25.164) is greater than the t table value (1.960). This result indicates that the difference between pre-test and post-test values is significant [26]. Significant value indicates 0.000 which indicates that this value is smaller than 0.05 . Then the null hypothesis is rejected and an alternative hypothesis is accepted [23], [27]. The test results state that there are differences in results between before using EPUB and after using EPUB.

The results of student responses to the Social Studies teaching materials based on multimedia EPUB on their experience using EPUB format digital books reveal that $92 \%$ students need teaching materials in digital format with practical reasons and provide easy access. Only $8 \%$ of students prefer the printed book format for ease of reading and as many as $74 \%$ of students choose the EPUB format compared to other digital book formats. Regardless of this finding, EPUB can be integrated directly with multimedia content.

\section{Conclusion}

The development of textbooks on the basic concepts of EPUB-based IPS can be acceptable and feasible to be functioned based on the results of expert validation in the effective category. The results of the field trial showed that there were differences in results between before and after using the EPUB-based IPS basic teaching materials. The high response of students to the use of the Social Studies teaching materials based on multimedia EPUB shows that books in digital format are more practical and easier to access and can be directly integrated with multimedia content. The high response of users of the Social Studies teaching materials based on multimedia EPUB can be a guide for the development of teaching materials in digital format, especially EPUB-based as a part of the Education 4.0 era.

Acknowledgements. This paper in conjuction with The 1st International Conference on Islam, Science and Technology (ICONIST 2018) in Malang, East Java.

\section{References}

[1] M. Jou, R. D. Tennyson, J. Wang, and S.-Y. Huang, "A study on the usability of E-books and APP in engineering courses: A case study on mechanical drawing," Comput. Educ., vol. 92-93, pp. 181-193, Jan. 2016. 
[2] Q. Pu, X. Zhu, D. Chen, and R. Zhang, "Analysis and optimization of PDF-to-EPUB in the digital publishing process,” Electron. Libr., vol. 36, no. 2, pp. 350-368, Apr. 2018.

[3] L. Johnson, R. Smith, H. Willis, A. Levine, and K. Hawood, The 2011 Horizon Report. Austin, Texas: The New Media Consortium.

[4] K. Lynch, "E-books: the future for publishers and libraries," Collect. Build., vol. 31, no. 2, pp. 78-80, Apr. 2012.

[5] S. Schomisch, M. Zens, and P. Mayr, "Are e-readers suitable tools for scholarly work? Results from a user test," Online Inf. Rev., vol. 37, no. 3, pp. 388-404, Jun. 2013.

[6] G. Cetin, O. Ozkaraca, M. Sakal, and E. Guvenc, "1576-6753-1-PB.pdf," Inf. Technol. Learn. TOOLS, vol. 58, pp. 129-140.

[7] S. Khusro, A. Latif, and I. Ullah, "On methods and tools of table detection, extraction and annotation in PDF documents," J. Inf. Sci., vol. 41, no. 1, pp. 41-57, Feb. 2015.

[8] S. Marinai, E. Marino, and G. Soda, "Conversion of PDF Books in EPUB Format," in 2011 International Conference on Document Analysis and Recognition, Beijing, China, 2011, pp. 478-482.

[9] P. Dewan, "Are books becoming extinct in academic libraries?" New Libr. World, vol. 113, no. $1 / 2$, pp. 27-37, Jan. 2012.

[10] B. De Meester et al., "A digital-first authoring environment for enriched e-books using EPUB 3," Inf. Serv. Use, vol. 34, no. 3-4, pp. 259-268, Dec. 2014.

[11] M. Hori, S. Ono, S. Kobayashi, K. Yamaji, T. Kita, and T. Yamada, "Learner Autonomy through the Adoption of Open Educational Resources Using Social Network Services and Multimedia E-textbooks," Asian Assoc. Open Univ. J., vol. 10, no. 1, pp. 23-35, Jun. 2015.

[12] Y. M. Harsono, "Developing Learning Materials for Specipic Purposes," p. 11.

[13] H. Shi, "eveloping Elearning Materials for Software Development Course," Int. J. Manag. Inf. Technol., vol. 2, no. 2, pp. 15-21, May 2010.

[14] P. Goodyear, "Educational design and networked learning: Patterns, pattern languages and design practice," Australas. J. Educ. Technol., p. 20, 2005.

[15] H. Hasbiyati and L. Khusnah, "Penerapan Media E-BOOK Bereksestensi EPUB untuk Meningkatkan Minat dan Hasil Belajar Siswa SMP pada Mata Pelajaran IPA," vol. 4, no. 1, p. 6, 2017.

[16] M. Aji and D. Widjanarko, "Pengembangan Media Pembelajaran Memahami dan Memeliharan Sistem Starter Tipe Konvensional Berbasis EPUB," vol. 16, no. 1, p. 6, 2016.

[17] O. W. Astuti and D. D. Kusumajanto, "Development of Electronic Book (E-Book) EPUBBased for Display Course," J. Pendidik. Bisnis Dan Manaj., vol. 3, no. 2, pp. 157-164, Sep. 2017.

[18] M. K. Abadi, H. Pujiastuti, and L. D. Assaat, "Development of Teaching Materials Based Interactive Scientific Approach towards the Concept of Social Arithmetic For Junior High School Student," J. Phys. Conf. Ser., vol. 812, p. 012015, Feb. 2017.

[19] S. Kalyuga, "Effects of Learner Prior Knowledge and Working Memory Limitations on Multimedia Learning," Procedia - Soc. Behav. Sci., vol. 83, pp. 25-29, Jul. 2013.

[20] B. Scott and C. Cong, "Evaluating course design principles for multimedia learning materials," Campus-Wide Inf. Syst., vol. 27, no. 5, pp. 280-292, Nov. 2010.

[21] B. Y. D. Satrio, "Modul Kimia Berbasis EPUB untuk Siswa Tunanetra: Materi Larutan Elektrolit dan Non-Elektrolit," INKLUSI, vol. 3, no. 1, p. 87, Feb. 2016.

[22] W. Dick, L. Carey, and J. O. Carey, The systematic design of instruction, Sixth edition. Boston: Pearson, 2014.

[23] R. D. Yockey, SPSS demystified. Taylor \& Francis, 2017.

[24] D. T. Campbell and J. C. Stanley, Experimental and quasi-experimental designs for research. Ravenio Books, 2015.

[25] A. Aljandali, Quantitative Analysis and IBM® SPSS® Statistics. Springer, 2016.

[26] I. Peers, Statistical analysis for education and psychology researchers: Tools for researchers in education and psychology. Routledge, 2006. 
[27] B. C. Cronk, How to use SPSS®: A step-by-step guide to analysis and interpretation. Routledge, 2017. 